Nor does the tale of his publications end with the above. Musis amicus, he traversed broad regions of other literature leading him to produce much miscellaneous matter in the capacity of editor. Thus he edited J. A. Froude's "Selected Essays"' in Longmans' British Classics for India (1915), Literary Essays (Macmillan, London, 1920), Morley's Select Essays, with introduction and notes (1923), Selected Essays of Matthew Arnold (1924), Selections from Gibbon's Decline and Fall of the Roman Empire (1925), R. L. Stevenson's Selected Essays, with introduction and notes (1923, 1925), Walter Pater's Selected Essays (1927), A. E. Becher's Personal Reminiscences (1930), and Viscountess Falkland's Chow Chow, with introduction and notes.

L. D. BARNE'Tt.

\title{
Walter Perceval Yetts
}

Professor W. Perceval Yetts, C.B.E., D.Lit., M.R.C.S., L.R.C.P., was born on 25th April, 1878, and died on 14th May, 1957. From Bradfield College he went to Lausanne before beginning his medical studies at London, where he qualified as physician and surgeon in 1903, and entered the Royal Naval Medical Service. He was placed first on passing out of Haslar in 1904, and was awarded the Admiralty Gold Medal in Naval Hygiene. His interest in Chinese art and culture was aroused on his first arrival on the China coast in H.M.S. Thistle, and the subject soon began to attract him irresistibly. In 1911 he was promoted Staff Surgeon, but resigned from the service on his marriage in the following year. Then came the turning point in his career. He was appointed Acting Physician to the British Legation in Peking, and at once fell under the spell of the beauty and dignity of that city. On the outbreak of war in 1914 he volunteered to rejoin the Navy, but was promptly commissioned in the R.A.M.C. in which he served with distinction and was awarded the O.B.E. After further service as a medical officer in government departments he retired and devoted himself entirely to the pursuits which had now come to occupy almost the whole of his leisure time.

He had already contributed articles on a variety of subjects to the Journal of this Society, in which he was destined to find some life-long friendships. Especially productive was that with L. C. Hopkins, the doyen of Chinese epigraphists in the West, whose writings in the Journal were then attracting keen attention. Yetts's 
interest in the ancient script, thus stimulated, led him inevitably to the study of the ritual bronzes and Buddhist sculpture, the most important vehicles of the inscriptions. His three volumes of the Eumorfopoulos Catalogue, published between 1929 and 1932, set a new standard of scholarship in Chinese art studies, and when the University of London decided to establish a Chair of Chinese Art and Archæology at the Courtauld Institute in the latter year, there could be no doubt as to who would be chosen to fill the post. He held it with distinction until his retirement as Professor Emeritus in 1946.

There have been few men to whom the name perfectionist could be more fairly applied. His sense of responsibility to his students and his readers for accurate information and balanced judgment was prodigious. It was reflected as much in the care with which he corrected his students' essays as in his attention to the smallest details of phrasing, referencing, and typography in his published work. He expected at least comparable standards in the work of his colleagues, and if such standards were not attained, his criticism, though always courteous, was outspoken and sometimes devastating. One consequence of this devotion to accuracy and completeness has been a sad disappointment to his friends. For more than twenty years he had been engaged on a great work to be called Ceremonial Bronzes of Ancient China. Had it been possible to publish it during the war, a book of reasonable size and completeness could have been produced, but since the war the spate of archæological discovery in China has demanded continual revision and re-writing. At the suggestion of friends in 1948 he executed a will appointing a literary executor, myself, to publish the book, if this should not have been achieved in his lifetime. The will, however, authorizes publication only of such sheets of manuscript and block proofs as bear the endorsement "Completed for Publication" and signed by the author. Unfortunately not a single sheet has been found so endorsed.

Of the few books bearing the name of Yetts the best known is The Cull Chinese Bronzes of 1939, a volume of essays inspired by objects in the collection of Mr. A. E. K. Cull. But his reputation rests largely on his articles in periodicals, which number nearly a hundred, apart from reviews. A majority appeared in our Journal or in The Burlington Magazine, and many continue to be of great value to students years after publication. His last work was his 
part in The Rulers of China, an important book on chronology in which he collaborated with the late Professor A. C. Moule. A feature of his writings is the excellence of his detailed drawings of decoration and inscriptions. He designed and executed the device on the cover of this Journal.

Yetts joined the Royal Asiatic Society in 1910, and served on its Council and Publications Committee for many years from 1916 until 1945, when he was made an Honorary Vice-President. He also supervised the cataloguing of the Chinese books in our Library. In 1956 he was awarded the Society's Triennial Gold Medal.

He was Chairman of a Selection Committee for the International Exhibition of Chinese Art at the Royal Academy in 1935-6, and Chairman of Council, The China Society, in the difficult war years, 1940-5. He served for many years on the Universities' China Committee in London and was an Honorary Member of the Oriental Ceramic Society. For his services to sinology he was awarded the C.B.E. in 1944 and the Order of the Brilliant Star (China) in 1947. He was a gifted artist in water-colour, etching, and tempera, while his neighbours in Buckinghamshire remember him with gratitude for his lively enterprise as local branch Chairman of the Council for the Preservation of Rural England.

S. Howard Hansford. 